\title{
Antibiotic resistance of Staphylococcus aureus isolated from raw cow and goat milk produced in the Tiaret and Souk Ahras areas of Algeria
}

\author{
Sofiane Tamendjari1 ${ }^{1,2}$ (D) Farida Afri Bouzebda ${ }^{1,2}$ (D), Lina Chaib ${ }^{1}$ (D) Hebib Aggad ${ }^{3}$, Mohammed Ramdani ${ }^{4}$ (i) and \\ Zoubir Bouzebda1,2 (i)
}

1. Department of Veterinary Science, Institute of Agronomic and Veterinary Sciences, University of Souk Ahras, Algeria; 2. Laboratory of Animal Productions, Biotechnologies and Health, University of Souk Ahras, Algeria; 3. Laboratory of Hygiene and Animal Pathology, University of Tiaret, Algeria; 4. Department of Zoology and Animal Ecology, Scientific Institute, University Mohammed $\mathrm{V}$ of Rabat, Morocco.

Corresponding author: Sofiane Tamendjari, e-mail: sofianetam06@gmail.com

Co-authors: FAB: bfafri@yahoo.fr, LC: linatam2308@gmail.com, HA: aggadhebib@yahoo.com,

MR: ramdanimed@gmail.com, ZB: z.bouzebda@univ-soukahras.dz

Received: 12-03-2021, Accepted: 09-06-2021, Published online: 27-07-2021

doi: www.doi.org/10.14202/vetworld.2021.1929-1934 How to cite this article: Tamendjari S, Bouzebda FA, Chaib L, Aggad H, Ramdani M, Bouzebda Z (2021) Antibiotic resistance of Staphylococcus aureus isolated from raw cow and goat milk produced in the Tiaret and Souk Ahras areas of Algeria, Veterinary World, 14(7): 1929-1934.

\begin{abstract}
Background and Aim: Staphylococcus aureus is a leading cause of infection in both humans and animals. Most livestock strains have shown antibiotic resistance to the many molecules used in veterinary therapeutics. This study aimed to assess the resistance patterns of these bacteria, we carried out our study in the Tiaret and Souk Ahras areas of Algeria.
\end{abstract}

Materials and Methods: We collected 116 samples of bovine and goat milk to detect $S$. aureus. We used a selective media to isolate the strains, followed by biochemically identifying the isolates. We determined the susceptibility of the strains to antibiotic molecules using the disk diffusion method and confirmed the methicillin-resistant $S$. aureus (MRSA) with oxacillin minimum inhibitory concentration (MIC).

Results: Our results showed that $26.72 \%$ of the samples were contaminated with $S$. aureus, and we recovered 31 isolates from the positive samples. We ascribed a high resistance profile to penicillin $\mathrm{G}(96.77 \%)$, fusidic acid $(67.74 \%)$, and tobramycin (45.16\%) and isolated 4MRSA strains.

Conclusion: The presence of $S$. aureus, including MRSA strains in raw milk, can present a public health hazard, because these strains can cause widespread food poisoning. This finding will be useful to the veterinarians to choose an adequate treatment and to sensitize livestock breeders and milk producers to ensure the health of consumers.

Keywords: antibiotic resistance, cow and goat raw milk, methicillin-resistant Staphylococcus aureus, Staphylococcus aureus.

\section{Introduction}

Staphylococcus aureus, one of the most dangerous species in the genus, lives on the skin and mucous membranes of many animals and can cause diseases according to the infection source. $S$. aureus infections, which can result from direct contact with the environment or by consuming food products, can cause a variety of diseases, ranging in severity from slight skin infections to more severe diseases such as pneumonia, endocarditis, osteomyelitis, septicemia, or toxic shock syndrome. This broad range of clinical syndromes results from a variety of extracellular components, including surface proteins, capsules, enzymes, and toxins [1].

S. aureus produces a wide array of toxins, which are responsible for food poisoning in animals and can cause a variety of infections, including skin infections

Copyright: Tamendjari, et al. Open Access. This article is distributed under the terms of the Creative Commons Attribution 4.0 International License (http://creativecommons.org/licenses/ by/4.0/), which permits unrestricted use, distribution, and reproduction in any medium, provided you give appropriate credit to the original author(s) and the source, provide a link to the Creative Commons license, and indicate if changes were made. The Creative Commons Public Domain Dedication waiver (http:// creativecommons.org/publicdomain/zero/1.0/) applies to the data made available in this article, unless otherwise stated. and mastitis in cows, goats, and sheep [2]. Mastitis in ruminants caused by clinical and sub-clinical forms can result in serious economic losses in the dairy sector by reducing production and lowering the quality of the milk [3].

The emergence of livestock-associated methicillin-resistant $S$. aureus (MRSA) is alarming because it is increasing worldwide and has a high risk of zoonotic transmission. Infection risk is especially high for professionals working in the agricultural industry [4] and probably for the community through the food chain [5]. The pathogenesis of $S$. aureus is aggravated by the acquisition of resistance to several antibiotics and other molecules with antimicrobial activity. In addition, MRSA is associated with patient care in hospitals and in the community. These strains are responsible for therapeutic failures and thus limit the choice of treatments for serious infections, causing increased costs for preventive and medical care [6].

This study aimed to assess the prevalence of $S$. aureus in raw cow and goat milk produced in the Tiaret and Souk Ahras regions of Algeria to evaluate the antibiotic resistance of these strains. This finding will be useful to the veterinarians to choose an 
adequate treatment and to sensitize livestock breeders and milk producers to ensure the health of consumers

\section{Materials and Methods}

Ethical approval

This study did not require any ethical approval from the University Animal Ethics Committee and was performed in accordance with Algerian laws and regulations on animal welfare.

\section{Study period and location}

The study was conducted from March 2016 to November 2019. The study was conducted at the Laboratory of Hygiene and Animal Pathology, University of Tiaret and in Laboratory of Animal Productions, Biotechnologies and Health, University of Souk Ahras.

\section{Sample collection}

We collected 116 samples, including 87 for bovine milk and 29 for goat milk. The bovine milk samples were collected from four farms in Tiaret (47 samples) and from three farms in Souk Ahras (40). However, the goat milk samples (29) were collected from only one goat farm in Ksar Chellala, Tiaret. All samples were collected aseptically in sterile boxes, transferred immediately to the laboratory with ice packs, and analyzed for the presence of S. aureus.

\section{S. aureus isolation and biochemical identification}

Isolation of $S$. aureus was done by spreading $0.1 \mathrm{ml}$ of dilution $\left(10^{-1}\right)$ on a Baird-Parker base (Conda Pronadisa, Spain), supplemented with egg yolk and potassium tellurite. Incubation of the plates was carried out at $37^{\circ} \mathrm{C}$ for $48 \mathrm{~h} \mathrm{[7].}$

From each positive sample, one colony with the typical aspects of $S$. aureus (black appearance, surrounded by a clear zone) was sub-cultured onto brain heart infusion agar (BHIB Conda, Pronadisa, Spain) to obtain a pure culture. The strains were submitted to Gram stain to confirm coccus morphology. The identification of isolates was completed using the following biochemical tests: Fermentation of mannitol, catalase, coagulase, and thermostable DNase.

\section{S. aureus isolates' antimicrobial susceptibility}

Antimicrobial susceptibility of strains was determined by the disk diffusion method on MuellerHinton agar (Conda, Pronadisa, Spain) according to the guidelines of the committee of the French Microbiology Society (FMS) [8] as well as the recommendations of the Algerian Antimicrobial Resistance Network [9]. The antibiotics disks used were from Liofilchem (Roeseto, Italy), and types and concentrations $(\mu \mathrm{g})$ follow: Penicillin $(\mathrm{PCN}) \mathrm{G}(10 \mathrm{UI})$, cefoxitin (FOX) (30), gentamicin (10), amikacin (30), tobramycin (TOB) (10), spiramycin (SP) (100), lincomycin (15), ofloxacin (5), tetracycline (TE) (30), trimethoprim/sulfamethoxazole $(1.25 / 23.75)$, chloramphenicol (C) (30), fosfomycin (FOS) (50), fusidic acid (FA) (10), and novobiocin (NO) (30). The strains were classified as susceptible or resistant according to the FMS breakpoints [8].

\section{Beta-lactamase production}

The detection of beta-lactamase (clover leaf test) was carried out for each strain with a PCN diameter of $\geq 29 \mathrm{~mm}$ [9].

\section{MRSA detection}

MRSA was detected using oxacillin (OXA) agar screen, FOX and OXA disk diffusion tests, and determination of the minimal inhibitory concentrations (MICs).

\section{OXA-resistance agar screening}

The bacteria suspension (adjusted to 0.5 McFarland turbidity standard) was inoculated on the OXA salt screen agar (Mueller-Hinton agar containing $4 \% \mathrm{NaCl}$ and $6 \mu \mathrm{g} / \mathrm{mL} \mathrm{OXA).} \mathrm{Plates} \mathrm{were} \mathrm{incu-}$ bated at $37^{\circ} \mathrm{C}$ for $24 \mathrm{~h}$, and any growth on the plate was regarded as methicillin resistance. Two $S$. aureus reference strains, ATCC 25923 and ATCC 43300, were used as negative and positive controls, respectively.

\section{MIC determination}

MIC determination was carried out according to the guidelines of the U.S. Clinical and Laboratory Standards Institute (CLSI) [10].

\section{Statistical analysis}

We performed the statistical analyses using Statistica 7 software (Statsoft, France).

\section{Results}

\section{S. aureus prevalence}

Of the 116 tested samples, $31(26.72 \%)$ were contaminated with $S$. aureus (Figure-1), with 33.33\% in cow milk (29/87 samples) and $6.89 \%$ in goat milk (2/29 samples). Cow milk showed a higher contamination rate as compared to goat milk $(\mathrm{p}<0.05)$, but we observed no significant difference between the cow milk of Tiaret and that of Souk Ahras (Figure-1).

\section{S. aureus isolates' antimicrobial resistance}

We found higher resistance rates for PCN G (96.77\%), FA (67.74\%), TOB (45.16\%), TE $(41.93 \%)$, and FOS $(41.93 \%)$. We observed low

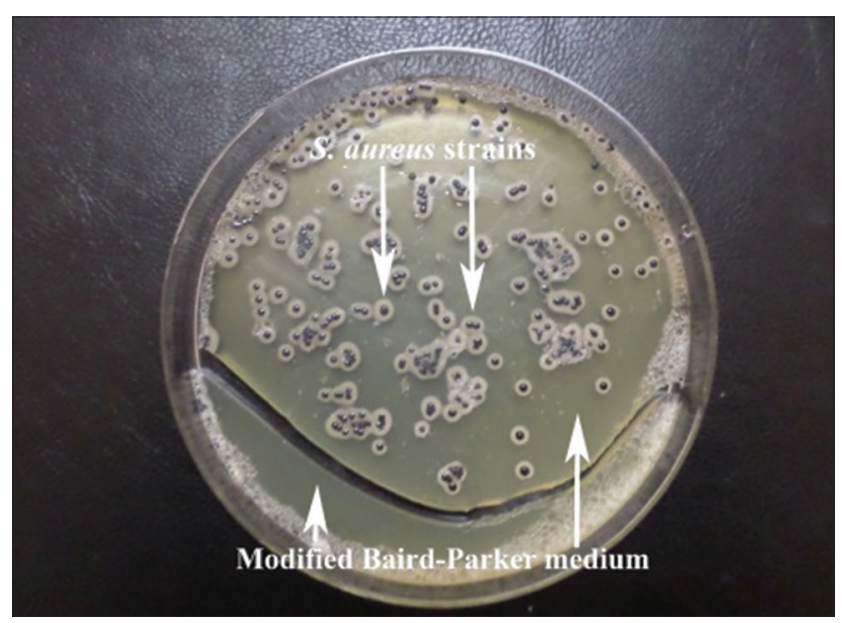

Figure-1: Staphylococcus aureus strains. 
resistance rates for $\mathrm{C}$, NO, lincomycin, and $\mathrm{SP}$ (Table-1 and Figure-2).

Classification and relationship between the 31 identified $S$. aureus strains are indicated by a dendrogram showing the groups according to their degree of rapprochement (Figure-3).

\section{Beta-lactamase production}

Almost all tested strains (90.32\%) were producing the beta-lactamase enzyme (Figure-4).

\section{MRSA strain detection}

The FOX disk diffusion test revealed 4 MRSA strains, two isolated from cow milk and two from goat milk. These strains were confirmed by the OXA agar test and the MIC determination against OXA (Table-2 and Figure-5). All were producing beta-lactamases.

\section{Discussion}

Our results are in agreement with those reported by Chaalal et al. [11] in a recent study in Algeria, which has indicated an $S$. aureus contamination rate of $32.6 \%$ in raw milk. However, a high prevalence of $S$. aureus has been reported in Egypt [12] and India [13], with values of $75 \%$ and $68 \%$, respectively.

We isolated two strains from 29 raw goat milk samples, with a rate of $6.89 \%$. This result agrees with that of Ekici et al. [14] in Turkey, who isolated three strains from 25 goat milk samples, but is lower than that reported by Pexara et al. [15] in Greece (31.4\%) and Bharathy et al. [13] in India (62.5\%). Merz et al. [16] in Switzerland found no isolates of $S$. aureus. The prevalence of $S$. aureus can vary according to hygienic conditions and animal management [17]. Almost all isolated strains were beta-lactamase producing $(96.77 \%)$. Our results differ from those announced by other studies indicating a low prevalence of these strains [18-20]. This high proportion of beta-lactamase-producing strains can be related to the overuse of PCN for the treatment of any infection at these farms, and the existence of these in the study area may be problematic for the treatment of $S$. aureus disease. The emergence of such strains in the environment requires monitoring [21]. We found that $12.9 \%$ of the isolated strains were resistant to methicillin, as were $3.44 \%$ of all the samples. Only a few studies have been conducted in Algeria to assess MRSA's prevalence in milk and other foods. Chaalal et al. [11] have reported a rate of $21.5 \%$ in various types of foods, including raw milk, meat, and pastries. Other studies conducted in Algeria have found a lower

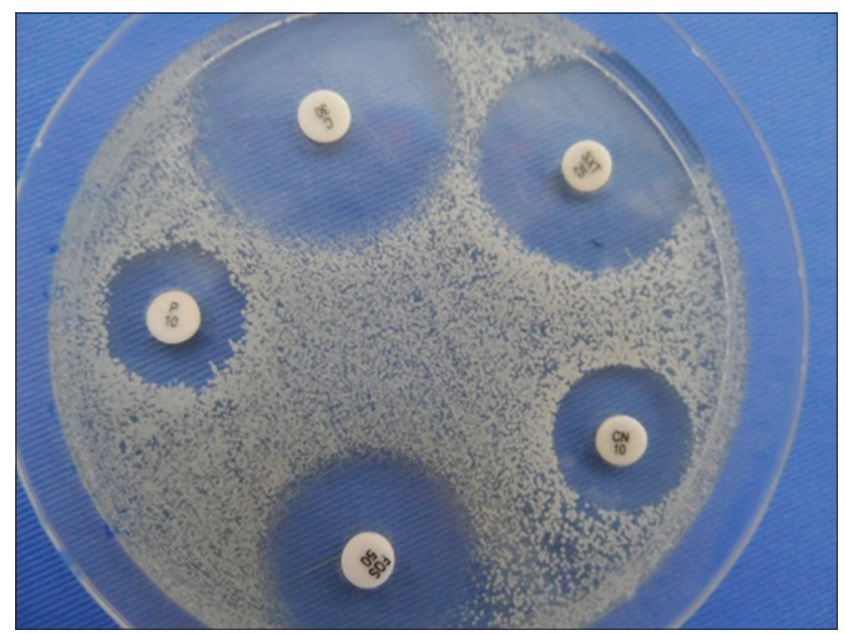

Figure-2: Result of antibiogram.

Table-1: Frequencies of resistance to the antibiotics tested.

\begin{tabular}{|c|c|c|c|}
\hline Families & $\begin{array}{l}\text { Groups of antibiotics according } \\
\text { to their significant differences }\end{array}$ & $\begin{array}{c}\text { Resistance and intermediate } \\
\text { to the antibiotic }(\%)\end{array}$ & $\begin{array}{l}\text { Sensitive to the } \\
\text { antibiotic }(\%)\end{array}$ \\
\hline \multirow[t]{2}{*}{ Beta-lactam } & Penicillina & 96.77 & 3.23 \\
\hline & Cefoxitinfg & 22.58 & 77.42 \\
\hline \multirow[t]{3}{*}{ Aminoglycosides } & Gentamicin de & $(41.93)$ & $(58.07)$ \\
\hline & Amikacind & 35.48 & 64.52 \\
\hline & Tobramycine & 45.16 & 54.84 \\
\hline \multirow[t]{2}{*}{ Macrolides } & Spiramycin ${ }^{\mathrm{jk}}$ & 6.45 & 93.55 \\
\hline & Lincomycin ${ }^{i j}$ & 9.67 & 90.33 \\
\hline Quinolones & Ofloxacin hi & 16.12 & 83.88 \\
\hline Tetracyclines & Tetracycline ${ }^{\text {de }}$ & 41.93 & 58.07 \\
\hline Sulfonamides & Trimethoprim/Sulfa methoxazolgh gh & $(19.35)$ & $(80.65)$ \\
\hline Chloramphenicol & Chloramphenicolij & 6.45 & 93.55 \\
\hline \multirow[t]{3}{*}{ Other molecules } & Fosfomycine & 41.93 & 58.07 \\
\hline & Fusidic acid ${ }^{b}$ & 67.74 & 32.26 \\
\hline & Novobiocin $n^{\mathrm{jk}}$ & 3.22 & 96.78 \\
\hline
\end{tabular}

Significant difference, $p=0.05$

Table-2: MICs, phenotypes, and beta-lactamase producing of methicillin-resistant Staphylococcus aureus strains.

\begin{tabular}{llcll}
\hline Strain & Origin & MIC $(\boldsymbol{\mu g} / \mathbf{m L})$ & Beta-lactamase producing & Antibiotic-phenotypes \\
\hline S1 & Raw cow's milk & 256 & + & P/FOS/CN/FOX/FC/SXT/AK/OFX/TOB \\
S2 & Raw cow's milk & 64 & + & P/FOX/FC \\
S3 & Raw goat's milk & 16 & + & P/CN/FOX/FC/OFX/TOB \\
S4 & Raw goat's milk & 16 & + & P/CN/FOX \\
\hline
\end{tabular}

MIC=Minimum inhibitory concentration 


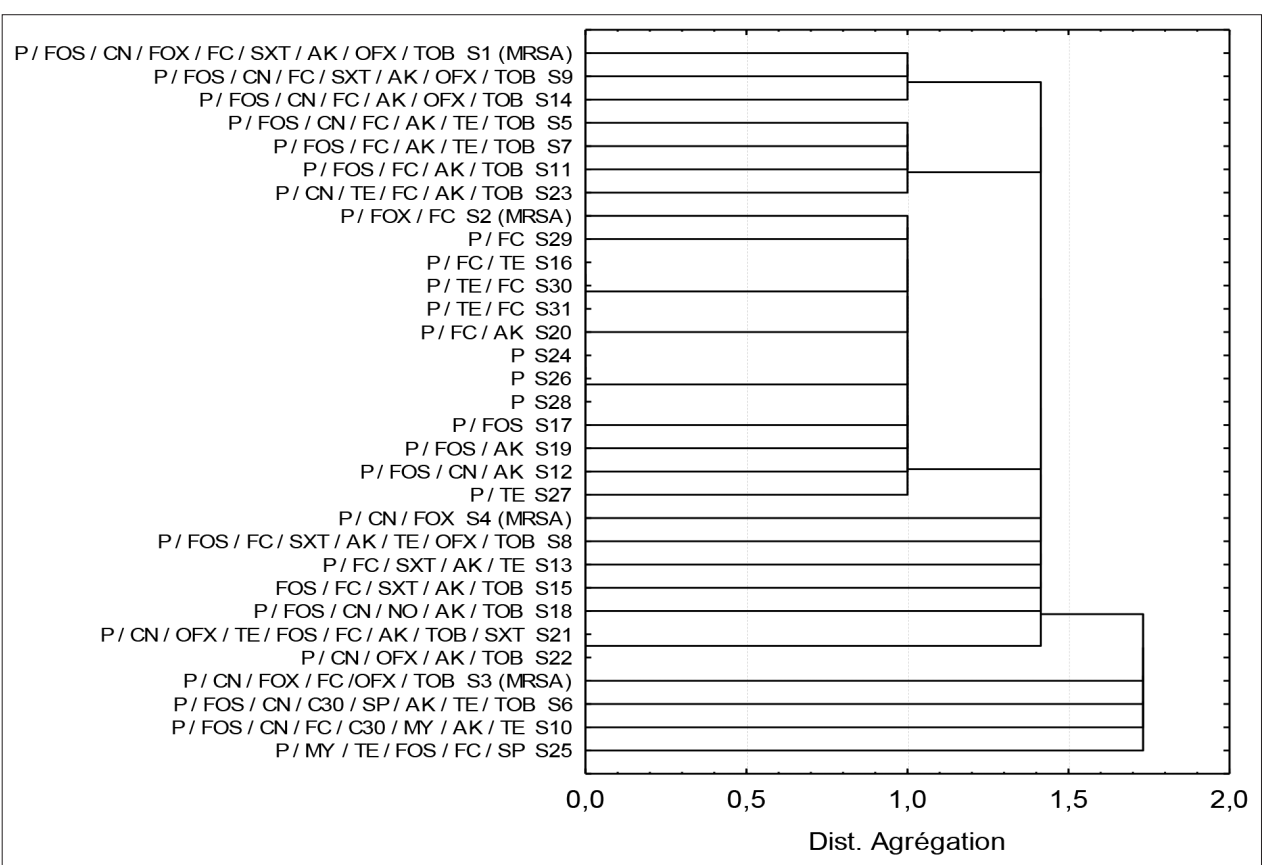

Figure-3: Classification of the identified strains of $S$. aureus according to their antibiotic susceptibility.

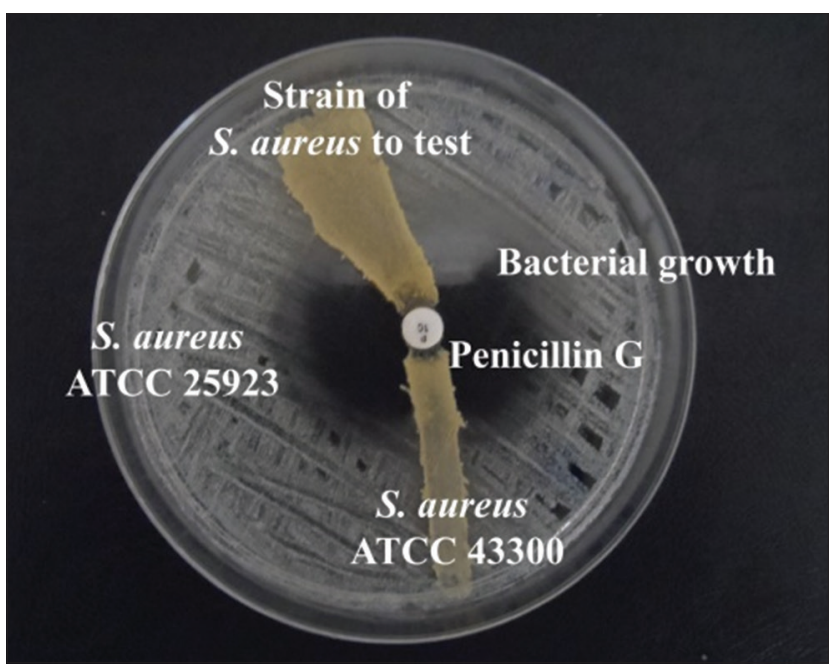

Figure-4: Beta-lactamase producing.

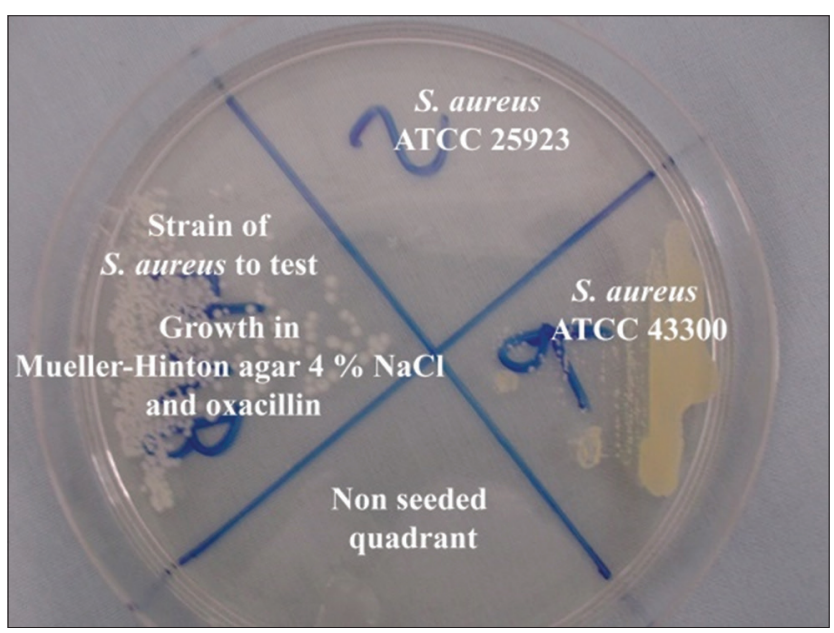

Figure-5: Methicillin-resistant Staphylococcus aureus test.

prevalence, with values of $4.1 \%-13.6 \%$ in raw milk and traditional dairy products [22-24], but, to the best of our knowledge, no study has examined goat milk. The MRSA contamination rate in our study was higher than was that of many other studies $[15,25,26]$ but was lower than that reported by Abd El Halem[27], with a value of $37.93 \%$. This diversity in prevalence rates among studies can be related to attributes such as sample source, geographic origin, sensitivity of identification methods, sample quantity, inappropriate antimicrobial administration, preventive practices, production techniques, and sample storage and handling $[24,28]$.

The MIC values for our results ranged from $64 \mu \mathrm{g} / \mathrm{mL}$ to $256 \mu \mathrm{g} / \mathrm{mL}$, higher than those reported by other studies (Table-3) [29-33]. We found that $80.64 \%$ (Figure-3) of the isolated strains were resistant to at least three antibiotic families and are multi-resistant according to the CLSI [34] definition. No isolate was sensitive to all antibiotics. Our results do not agree with those of other studies in Algeria. Chaalal et al. [11] have reported that 33.3\% of the $S$. aureus strains mainly isolated from raw milk and raw meat were multi-drug resistant, with $45.7 \%$ resistant to one antibiotic and $20.0 \%$ sensitive to all the antibiotics tested [11]. Matallah et al. [23] and Titouche et al. [22] have reported that 3.15\% and $23.18 \%$ of their strains were multi-resistant. Similar findings have been obtained in Italy [25] and Russia [35].

Food may be a vector for antibiotic-resistant bacteria and for the spread of antibiotic resistance, which can be transmitted through the consumption of food products of an animal origin [36]. Recent studies have highlighted the potential role of food in the spread of MRSA lineages in humans [37], and S. aureus is considered an important cause of zoonotic diseases and a potential source of transmission of the MRSA strains 
Table-3: Minimum inhibitory concentration of certain strains of Staphylococcus aureus.

\begin{tabular}{lclc}
\hline Study & $\begin{array}{c}\text { Methicillin-resistant } \\
\text { Staphylococcus aureus strain \% }\end{array}$ & Origin & $\begin{array}{c}\text { Minimum inhibitory } \\
\text { concentration }(\boldsymbol{\mu g} / \mathbf{m L})\end{array}$ \\
\hline Our study & 2.29 & Raw cow's milk & $64-256$ \\
Our study & 6.89 & Raw goat's milk & 16 \\
Moreno-Grúa et al. [29] & 12.5 & Commercial rabbits & $8-256$ \\
Krupa et al. [30] & 0.8 & Chicken meat & 64 \\
Febler et al. [31] & 37.2 & Food and food products of & $4-32$ \\
Moon et al. [32] & 2.8 & poultry origin & $\leq 4-256$ \\
Lee [33] & 6.41 & Bovine mastitis & $2-128$ \\
\hline
\end{tabular}

between livestock and humans through handling and consuming contaminated food [38].

\section{Conclusion}

In this study, we report for the $1^{\text {st }}$ time the presence of MRSA in raw goat milk in Algeria. However, bovine milk was more contaminated by $S$. aureus than was goat milk. The high presence of multidrug-resistant $S$. aureus, including the MRSA strains, raises questions about the persistent use of antibiotics as the a priori treatment for udder and other infections on the farm. Our results indicate the need for continuous monitoring and improvement of the hygienic quality of raw milk by ensuring proper handling and production to reduce the spread of multidrug-resistant bacteria to foods of animal origin.

\section{Authors' Contributions}

ST and LC: Sample collection, microbiological analysis of samples and supply of certain products. ST: Writing of the manuscript and statistical analysis. FAB: Follow-up of the study, supply of some products, and correction of the manuscript. HA: Follow-up of the study and supply of some products. MR and ZB: Follow-up of the study and correction of the manuscript. All authors have read and approved the final manuscript.

\section{Acknowledgments}

The authors are thankful to the Department of Veterinary Sciences and the Laboratory of Animal Productions, Biotechnologies and Health, Institute of Agronomic and Veterinarian Sciences, University of Mohamed Cherif Messaâdia, Souk Ahras, Algeria. The authors are also thankful to Laboratory of Hygiene and Animal Pathology, University of Tiaret, Algeria for providing all the facilities to carry out the present study. The authors did not receive any funds for this study.

\section{Competing Interests}

The authors declare that they have no competing interests.

\section{Publisher's Note}

Veterinary World remains neutral with regard to jurisdictional claims in published institutional affiliation.

\section{References}

1. Lowy, F.D. (1998) Staphylococcus aureus infections. $N$. Engl. J. Med., 339(8): 520-532.

2. Bierowiec, K., Płoneczka-Janeczko, K. and Rypuła, K. (2016) Is the colonisation of Staphylococcus aureus in pets associated with their close contact with owners? PLoS One, 11(5): $\mathrm{e} 0156052$

3. Bergonier, D., De Crémoux, R., Rupp, R., Lagriffoul, G. and Berthelot, X. (2003) Mastitis of dairy small ruminants. Vet. Res., 34(5): 689-716.

4. Guardabassi, L., Larsen, J., Weese, J., Butaye, P., Battisti, A., Kluytmans, J., Lloyd, D. and Skov, R. (2013) Public health impact and antimicrobial selection of meticillin-resistant staphylococci in animals. $J G A R, 1(2): 55-62$.

5. Kluytmans, J. (2010) Methicillin-resistant Staphylococcus aureus in food products: Cause for concern or case for complacency? Clin. Microbiol. Infect., 16(1): 11-15.

6. Cuny, C., Köck, R. and Witte, W. (2013) Livestock associated MRSA (LA-MRSA) and its relevance for humans in Germany. IJMM, 303(6-7): 331-337.

7. ISO. (1999) Microbiology of Food and Animal Feeding Stuffs-horizontal Method for the Enumeration of Coagulase-positive Staphylococci (Staphylococcus aureus and Other Species): Part 1: Technique Using Baird-parker Agar Medium. ISO, Geneva, Switzerland.

8. CA-SFM. (2013) Antibiogramme Vétérinaire du COMITÉ de L'antibiogramme de la Société Française de Microbiologie. Société Française de Microbiologie, Paris. p8-12.

9. Ammari, H. (2011) Standardisation de L'antibiogramme à L'échelle Nationale (Médecine Humaine et Vétérinaire). $6^{\text {th }}$ éd. Réseau Algérien de la Surveillance de la Résistance Des Bactéries Aux Antibiotiques, Algérie. p45-46.

10. CLSI. (2015) Performance Standards for Antimicrobial Susceptibility Testing; Twenty-fifth Informational Supplement. CLSI document M100-S25. CLSI, Wayne, PA.

11. Chaalal, W., Chaalal, N., Bourafa, N., Kihal, M., Diene, S.M. and Rolain, J.M. (2018) Characterization of Staphylococcus aureus isolated from food products in Western Algeria. Foodborne Pathog. Dis., 15(6): 353-360.

12. Al-Ashmawy, M.A., Sallam, K.I., Abd-Elghany, S.M., Elhadidy, M. and Tamura T. (2016) Prevalence, molecular characterization, and antimicrobial susceptibility of methicillin-resistant Staphylococcus aureus isolated from milk and dairy products. Foodborne Pathog. Dis., 13(3): 156-162.

13. Bharathy, S., Gunaseelan, L., Porteen, K. and Bojiraj, M. (2015) Prevalence of Staphylococcus aureus in raw milk: Can it be a potential public health threat. Int. J. Adv. Res., 3(2): 801-806

14. Ekici, K., Bozkurt, H. and Isleyici, O. (2004) Isolation of some pathogens from raw milk of different milch animals. Pak. J. Nutr., 3(3): 161-162.

15. Pexara, A., Solomakos, N., Sergelidis, D., Angelidis, A.S. and Govaris, A. (2016) Occurrence and antibiotic resistance of enterotoxigenic Staphylococcus aureus in raw ovine and caprine milk in Greece. Dairy Sci. Tech., 96(3): 345-357. 
16. Merz, A., Stephan, R. and Johler, S. (2016) Staphylococcus aureus isolates from goat and sheep milk seem to be closely related and differ from isolates detected from bovine milk. Front. Microbiol., 7: 319.

17. Ateba, C.N., Mbewe, M., Moneoang, M.S. and Bezuidenhout, C.C. (2010) Antibiotic-resistant Staphylococcus aureus isolated from milk in the Mafikeng Area, North West province, South Africa. S. Afr. J. Sci., 106(11-12): 1-6.

18. Paludi, D., Vergara, A., Festino, A.R., Di Ciccio, P., Costanzo, C., Conter, M., Zanardi, E., Ghidini, S. and Ianieri, A. (2011) Antimicrobial resistance pattern of methicillin-resistant Staphylococcus aureus in the food industry. J. Biol. Regul. Homeost. Agents., 25(4): 671.

19. Serieys, F. and Gicquel-Bruneau, M. (2005) Homogénéité intra-troupeau des souches de Staphylococcus aureus de mammites sub-cliniques pour la production de $\beta$-lactamase et la résistance à la pénicilline. Renc. Rech. Ruminant., 12: 267-270.

20. Öncel, T., İça, T. and Akan, M. (2004) Beta lactamase production rate and antimicrobial susceptibility of Staphylococcus aureus isolated from clinical and subclinical mastitis cases in Turkey. Rev. Med. Vet., 155(7): 385-388.

21. Hryniewicz, M.M. and Garbacz, K. (2017) Borderline oxacillin-resistant Staphylococcus aureus (BORSA)-a more common problem than expected? J. Med. Microbiol., 66(10): 1367-1373.

22. Titouche, Y., Hakem, A., Houali, K., Meheut, T., Vingadassalon, N., Ruiz-Ripa, L., Salmi, D., Chergui, A., Chenouf, N. and Hennekinne, J. (2019) Emergence of methicillin-resistant Staphylococcus aureus (MRSA) ST8 in raw milk and traditional dairy products in the Tizi Ouzou area of Algeria. J. Dairy Sci., 102(8): 6876-6884.

23. Matallah, A.M., Bouayad, L., Boudjellaba, S., Mebkhout, F., Hamdi, T.M. and Ramdani-Bouguessa, N. (2019) Staphylococcus aureus isolated from selected dairies of Algeria: Prevalence and susceptibility to antibiotics. Vet. World, 12(2): 205.

24. Titouche, Y., Houali, K., Ruiz-Ripa, L., Vingadassalon, N., Nia, Y., Fatihi, A., Cauquil, A., Bouchez, P., Bouhier, L. and Torres, C. (2020) Enterotoxin genes and antimicrobial resistance in Staphylococcus aureus isolated from food products in Algeria. J. Appl. Microbiol., 129(4): 1043-1052.

25. Giacinti, G., Carfora, V., Caprioli, A., Sagrafoli, D., Marri, N., Giangolini, G., Amoruso, R., Iurescia, M., Stravino, F. and Dottarelli, S. (2017) Prevalence and characterization of methicillin-resistant Staphylococcus aureus carrying mecA or mecC and methicillin-susceptible Staphylococcus aureus in dairy sheep farms in central Italy. J. Dairy Sci., 100(10): 7857-7863.

26. Basanisi, M., La Bella, G., Nobili, G., Franconieri, I. and La Salandra, G. (2017) Genotyping of methicillin-resistant Staphylococcus aureus (MRSA) isolated from milk and dairy products in South Italy. Food Microbiol., 62: 141-146.

27. Abd El Halem, S.G. (2019) Prevalence and antibiotic resistance of Staphylococcus aureus isolated from raw milk and dairy products collected from Alexandria, Egypt. Alex. J. Fd. Sci. Technol., 16(2): 25-33.

28. Touch, V. and Deeth, H. (2009) Microbiology of raw and market milks. In: Tamime, A.Y., editor. Milk Processing and Quality Management. Wiley-Blackwell, United Kingdom. p48.

29. Moreno-Grúa, E., Pérez-Fuentes, S., Muñoz-Silvestre, A., Viana, D., Fernández-Ros, A.B., Sanz-Tejero, C., Corpa, J.M. and Selva, L. (2018) Characterization of livestock-associated methicillin-resistant Staphylococcus aureus isolates obtained from commercial rabbitries located in the Iberian Peninsula. Front. Microbiol., 9: 1812.

30. Krupa, P., Bystroń, J., Bania, J., Podkowik, M., Empel, J. and Mroczkowska, A. (2014) Genotypes and oxacillin resistance of Staphylococcus aureus from chicken and chicken meat in Poland. Poult. Sci., 93(12): 3179-3186.

31. Febler, A.T., Kadlec, K., Hassel, M., Hauschild, T., Eidam, C., Ehricht, R., Monecke, S. and Schwarz, S. (2011) Characterization of methicillin-resistant Staphylococcus aureus isolates from food and food products of poultry origin in Germany. Appl. Environ. Microbiol., 77(20): 7151-7157.

32. Moon, J.S., Lee, A.R., Kang H.M., Lee, E.S., Kim, M.N., Paik, Y., Park, Y.H., Joo, Y.S. and Koo, H. (2007) Phenotypic and genetic antibiogram of methicillin-resistant staphylococci isolated from bovine mastitis in Korea. J. Dairy Sci., 90(3): 1176-1185.

33. Lee, J.H. (2003) Methicillin (Oxacillin)-resistant Staphylococcus aureus strains isolated from major food animals and their potential transmission to humans. Appl. Environ. Microbiol., 69(11): 6489-6494.

34. CLSI. (2007) Performance Standards for Antimicrobial Susceptibility Testing; Seventeenth Informational Supplement. CLSI document M100-S17. CLSI, Wayne, PA.

35. Artem'eva, O.A., Nikanova, D.A., Kotkovskaya, E.N., Gladyr, E., Dotsev, A. and Zinovieva, N.A. (2016) Antibiotic-resistance profile of Staphylococcus aureus strains isolated from milk of high yield cows in central Russia. Sel'skokhozyaistvennaya Biol., 51(6): 867-874.

36. Ruiz, L. and Alvarez-Ordóñez, A. (2017) The role of the food chain in the spread of antimicrobial resistance (AMR). In: Boukherroub, R., Szunerits, S. and Drider, D., editors. Functionalized Nanomaterials for the Management of Microbial Infection. $1^{\text {st }}$ ed. Elsevier, Lille, France. p23-47.

37. Oniciuc, E.A., Nicolau, A.I., Hernández, M. and RodríguezLázaro, D. (2017). Presence of methicillin-resistant Staphylococcus aureus in the food chain. Trends Food Sci. Tech., 61: 49-59.

38. Pereyra, E.A., Picech, F., Renna, M.S., Baravalle, C., Andreotti, C.S., Russi, R., Calvinho, L.F., Diez, C and Dallard, B.E. (2016) Detection of Staphylococcus aureus adhesion and biofilm-producing genes and their expression during internalization in bovine mammary epithelial cells. Vet. Microbiol., 183: 69-77. 